\title{
Kan man trene seg smart?
}

Forskjellig type trening gir ulik effekt på hjernen hos rotter.

Hos voksne gnagere er det påvist at aerob trening øker nevrogenesen i hippocampus, men det er uklart om høyintensitetstrening og styrketrening har samme effekt. I en ny studie, publisert i tidsskriftet Journal of Physiology, forsøker forskere å besvare dette spørsmålet (1). I en rekke eksperimenter ble rotter, som allerede var selektert for å respondere forskjellig på trening, eksponert

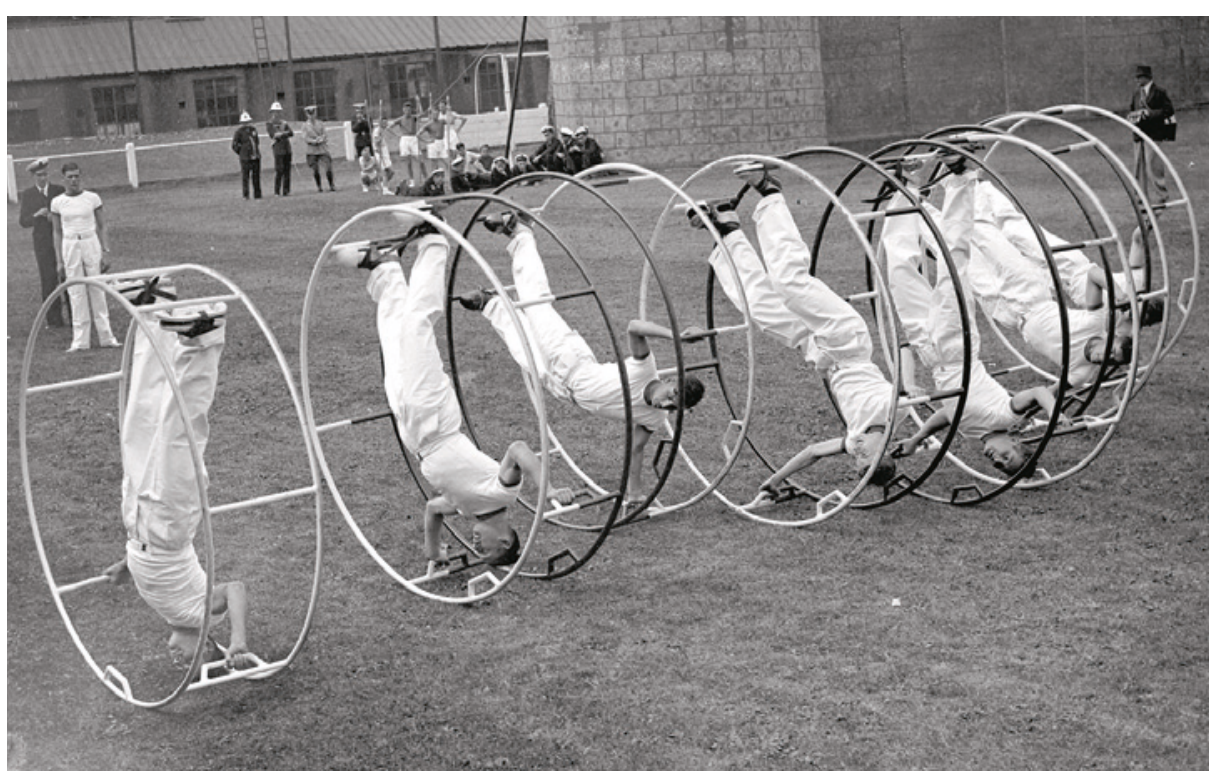

Illustrasjonsfoto: Topfoto/Scanpix

\section{Nattevakt gir dårligere kognitiv prestasjon}

\section{Legers kognitive evner svekkes etter en nattevakt, viser ny studie.}

I en fransk studie som nylig er publisert $\mathrm{i}$ tidsskriftet Intensive Care Medicine, ønsket man å undersøke hvilken virkning en nattevakt ved intensivavdelingen hadde på legenes kognitive evner (1).

51 intensivleger fra tre forskjellige intensivavdelinger ble undersøkt, derav 24 overleger og 27 leger i spesialisering. Fire kognitive ferdigheter - hukommelse, oppfatning, kognitiv fleksibilitet og hvor raskt informasjon ble bearbeidet - ble testet etter en nattevakt og etter en natt med hvile. Alle disse ferdighetene ble forverret etter en nattevakt. Det var ingen signifikant forskjell mellom for forskjellige former for trening over en seks til åtte ukers periode.

Rotter som sprang frivillig i et løpehjul, hadde større nevrogenese $\mathrm{i}$ hippocampus enn sedate rotter, mens høyintensitetsrottene, som løp intervaller på tredemølle, ikke oppnådde denne effekten. I et annet eksperiment utviste rotter som ble eksponert for utholdenhetstrening, større grad av nevro- genese i hippocampus enn dem som gjorde styrketrening, der en vektskive ble festet til halen, før de måtte klatre på en stige. Det ble ikke påvist forskjell i nevrogenese mellom rotter som var sedate eller utførte styrketrening.

- Studien har god design, resultatene er klare og virker pålitelige, sier Terje Lømo, professor emeritus i fysiologi ved Universitetet i Oslo. - Studien understreker betydningen av genetisk predisposisjon for effekt av trening.

- Resultatene bekrefter mye av det vi vet fra før, men byr også på overraskelser som at styrketrening og høyintensitetstrening er uten effekt på nevrogenesen til tross for klare effekter på muskelstyrke, sier Lømo. - Vi kan imidlertid ikke trekke sikre slutninger, ettersom sammenhengene er komplekse og påvirket av mange ukontrollerbare faktorer, blant annet stress og variabel motivasjon, påpeker han.

- Studien sier neppe mye om hvordan mennesker bør trene for å oppnå størst mulig positiv effekt på mental kapasitet, utover det vi allerede vet. Dertil er avstanden fra rotte til menneske for stor og søkelyset på nevrogenese i hippocampus for snevert, sier Lømo.

\section{Ketil Slagstad}

Tidsskriftet

\section{Litteratur}

1. Nokia MS, Lensu S, Ahtiainen JP et al. Physical exercise increases adult hippocampal neurogenesis in male rats provided it is aerobic and sustained. J Physiol 2016. E-publisert 4.2. 2016.

hvile hjemme, og resultatene var uavhengig av grad av erfaring hos legene, selvrapportert søvnlengde og grad av subjektiv slitenhet. Studiens begrensninger er bl.a. at det ikke forelå objektive målinger av søvnlengde, at deltagerne ikke ble spurt om subjektive mål for søvnkvalitet, og at kontrollmålingene ikke også ble gjort på slutten av en ordinær arbeidsdag. Dermed er det vanskelig å vite om årsaksforholdet skyldes søvnmangel eller stress, sier Laugsand. naturvitenskapelige universitet. - Funnene er i samsvar med tidligere studier som har vist at regulert og redusert arbeidstid hos leger kan bidra til bedre beslutningsevne med potensial til å redusere antall medisinske avvik.

- Legene presterte signifikant dårligere på validerte kognitive tester på slutten av en nattevakt, sammenlignet med etter én natts

\section{Liv-Ellen Vangsnes}

Tidsskriftet

Litteratur

Maltese F, Adda M, Bablon A et al. Night shift decreases cognitive performance of ICU physicians. Intensive Care Med 2016; 42: 393-400. 